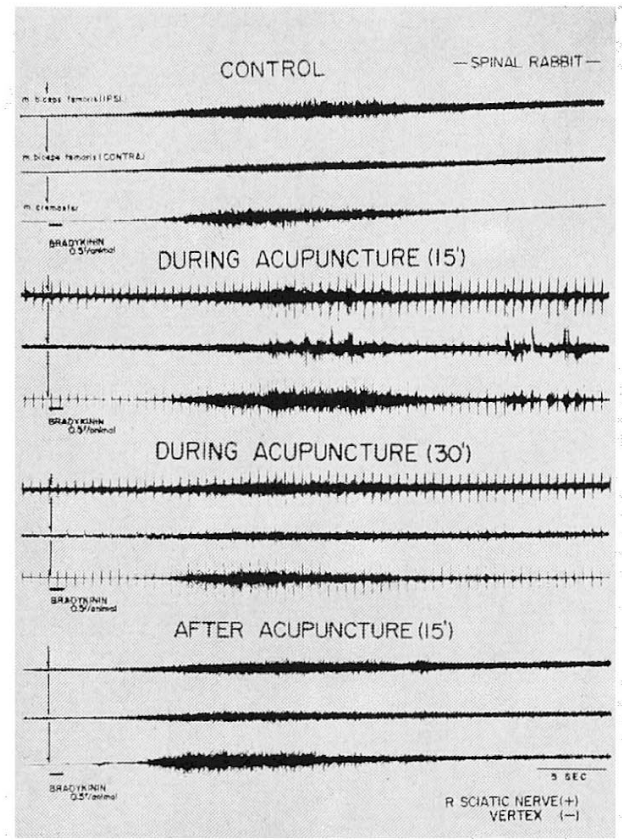

以上の実験結果から，Bradykinin を動注した時に生 じる家鬼の疼痛反応が, 臨床で使用しているハリ麻酔器 に上って抑えられることと, その抑制機序には脊㗙より 上位の中枢の関与が必要であることが判明した。また， 通電中止後も除痛効果が持続しているということは, 臨 床上興味深い知見である術後疼痛の緩解との関連性を示 唆するものであり，今後このことに関してさらに実験を すすめてゆきたいと考える。

質問 井上鉄三（国立医療センター），1）扁桃の疼 痛はどんなものか, Grading あれば教えてほしい，

2）出血量如妸か。応答 栗山博 咽頭痛を自 発痛之與下痛にわけ, それぞれ程度によって0〜 4 亿わ け, 術後 5 時間観察した. 出血は局麻剤による手術と比 べてほとんど差はない＼cjkstart質問 池松武之亮（千葉 県)，ハリ麻酔は術前に要する時間と持続時間はどの位 か. 応答 栗山 博 通電開始から手術開始まで15 分〜20分要する。ハリと八リ麻酔器があれば行なえる. 費用はさほど高くない

(B 80-1221-00024)

図 2

\title{
146. 味覚障害における血清亜鉛值と亜鉛内服療法
}

\section{○冨田 寛・奥田雪雄・石井泰平・岸 拓三 (日大)}

血中微量金属のらち亜鉛值の低下が, 生長阻害, 皮虔 および毛鬅や爪などの付属器の損傷, 創傷治痳の遅延, 生殖機能不全, 食欲不振, そして味覚障害を起こすこと が最近わかってきた。

ヒトに沶ける亜鉛欠乏症も，Prasad による中東に住 む男性のコビトの研究, Michaëlsson による腸性肢端皮 虞炎, そして岡田らの高カロリ一輸液中にみられた症例 報告などから，次第にその様相がはっきりしてきた，

亜鉛欠乏が始何なるメカニズムによって味営減退, 異 味症に関倸しているのかは未だわからないが，亜鉛の経 口投与で回復する症例のあることが Henkin らによっ て報告されている.わ机れも種々の原因による味覚障 害患者の血清亜鉛值の変動を研究するとともに, 硫酸亜 鉛の内服療法を試み，みるべき成果を挙げているので報 告する.

研究方法：昭和51年 12 月末日までの 2 年間に, 日大の 味覚外来在, 味觉異常主訴として訪孔た73例につい 下, 無選択的に血清亜鉛值を原子吸光法で測定した。そ
のらち嗅覚脱失に基づく味覚異常で, 味覚機能は正常で あった 5 例は，統計的処理から除いた。

今回の発表までに結論の出た，硫酸要鉛内服療法を試 みた患者数は26例である.

硫酸带鉛の 1 日投与量は $200 \mathrm{mg}$ から $400 \mathrm{mg}$ である.

研究成績ならびに考察：今回の研究の対象となった症 例の，味覚障害の原因と，測定した血清亜鉛值を表に示 した.

原因は種々であるが，特発性のものが最も多かった。 血清亜鉛值の検討は，男性35例，女性33例，計68例で

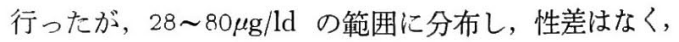
平均 $59 \mu \mathrm{g} / \mathrm{dl}$ であった。原美によれば，正常值は 54 $138 \mu \mathrm{g} / \mathrm{dl}$ の間にあり, 平均值は男性 $94 \mu \mathrm{g} / \mathrm{dl}$, 女性 78 $\mu \mathrm{g} / \mathrm{dl}$ であるので，味喾障害における血清西鉛値は有意 に低していた。

正常人では性差があるのに，味営障害を訴える症例で は性差がなくなり，一様に血清亜鉛值が低下していた。 また表 1 のごとく原因別に分類しても，味覚障害を訴え 
表 1

味覚障害の原因と血清垔鉛値

\begin{tabular}{|c|c|c|c|c|}
\hline 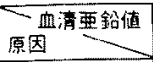 & 低下 & 限界 & 正常 & 計 \\
\hline 口腔内病変 & 4 & 2 & 1 & 7 \\
\hline 伝導路障害 & 0 & 1 & 0 & 1 \\
\hline 心 因 性 & 1 & 3 & 1 & 5 \\
\hline 頡部外傷 & 2 & 0 & 0 & 2 \\
\hline 感 冒 & 0 & 4 & 1 & 5 \\
\hline 㖵 覚 性 & 1 & 4 & 0 & 5 \\
\hline 全身疾㤟 & 7 & 3 & 2 & 12 \\
\hline 菜物の副作用 & 4 & 2 & 4 & 10 \\
\hline 特 発 性 & 17 & 5 & 4 & 26 \\
\hline 計 & 36 & 24 & 13 & 73 \\
\hline
\end{tabular}

低下：59 $\mathrm{\mu g} / \mathrm{d}$ 以下

限界: $60-69 \mu \mathrm{g} / \mathrm{d}$

正常: $70 \mu \mathrm{g} / \mathrm{d}$ 以上

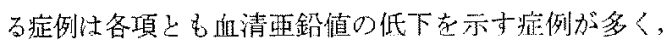
昧党異常を起こ寸きっかけ悼っても，本態は同一の上 うにみえる。

発症後日数，または服薬後発症までの期間の長さと血 清亜鉛值の関係在，特発性味覚障害10例，薬物の副作用 に基つく味覚障害例について調心゙くみたが，発症後忠た 虹服薬後の日数が長いと血清严鉛值の低下が著しいとい う相関は，晛在のとこ万認为られない。

これは味賞障害発症の域值に個人差があること上，眊 物の副作用については作用点の異なるものが含まれてい

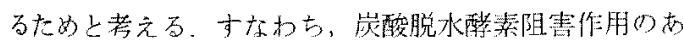
る降压制尿剂や SH 基老持つ菒剂の上うに，兆鉛をキレ 一トする薬郕を服用している時には服䔁期閒上理鉛值に 相関があるが，抗らうつ棛やある種の鎮吐剂の上うに脑

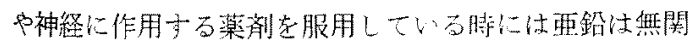
倸のよらである。

亜鉛は従来䙳ら外用薬として用いられ，内服療法心霖 史付大変新しい，

われわれは精製硫酸要鉛 $100 \mathrm{mg} 1$ 老カプセル上し， 通常1 日3カプセル在食後に服用させ，症状に㐫じ 4 か ら1カプセルの間で增減させた。 2 年閂の使用経験で副 作用蛙認めていない

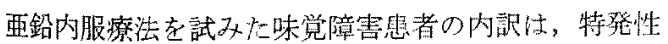

19例、薬物の副作用 4 例，感冒俊 1 例。刘照上して血清

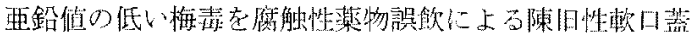
病装各例瞋いた。

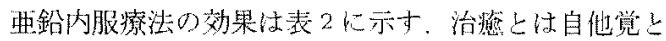
も味覚が正常に復したもの。著效とは味觉㭘查值は正常 化したにもかかわらず自覚的になお罢常感在残すをの， ならびに滤紙デスク法で全ての味留が 2 段階以上改善を みたものをいう，有効とは全ての味筈で1段階，または

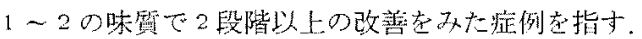

表 2

\section{悪鉛内服療法の効果}

\begin{tabular}{|c|c|c|c|c|c|}
\hline 種類 & 治虑 & 著効 & 有効 & 無効 & 計 \\
\hline 特 発 性 & 9 & 5 & 3 & 2 & 19 \\
\hline 蔡物の副作用 & 0 & 1 & 1 & 2 & 4 \\
\hline 感 晅 後 & 0 & 1 & 0 & 0 & 1 \\
\hline 対 照 & 0 & 0 & 0 & 2 & 2 \\
\hline 計 & 9 & 7 & 4 & 6 & 26 \\
\hline
\end{tabular}

表のごとく味觉障害に対する亜鉛内服燎法り有効晾社 83\%であり，特に特発性無味症に著効を示した。この群 では血清带䤩值汃著しい低下を示さなかった1症例（74 $\mu \mathrm{g} / \mathrm{d} \mathrm{D})$ 已治䍂せし如得た。

発症㣪日数10力月以内のものには全例有效で市った。

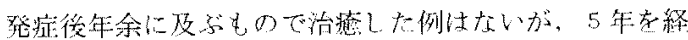
た症例で有効な例があった。

結論：味觉障害における血清事鉛值の測定は，必ず行 うぶき渙查である。

西鉛内服療法法，上〈に特発性味覚障㫪には必式試み る心゙き治療法である。原因の明らかな昧覚障慧例は，原 因索取除くばかりでなく，血中两鉛值が低下してい当場 合には，里鉛内服療法を行らことによって棟觉障㫪を速 やかに回復させることができる。

質問 服部浩（神戸大），1）投与期間の汽定洗上遠 隔成績，2）例えば甘味だけの障害㭙はじらなっている か，3）特発性以外の多くの原因誘因があげられている が，それらが血清亚铅值の低下を来す譏序はとら侤える 加。応答 冨田 寛 (1)專門外来の都合上, 週单位 で效果をみているが，普通 $1 〜 2$ 週で血中亚鉛值の上㬎

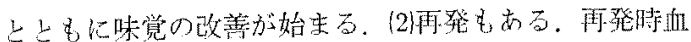




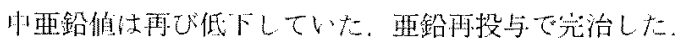

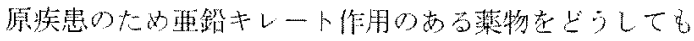

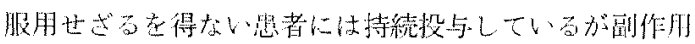

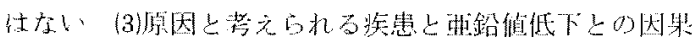

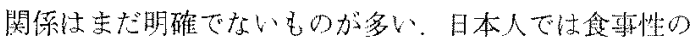

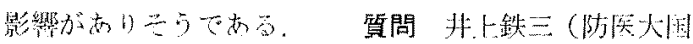

立医療七之ター，1） 1) Hypogensia, Dysgensia, Cacogensia 等の Terminology も，日本語で確主される

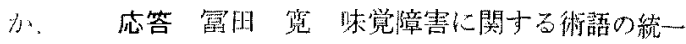

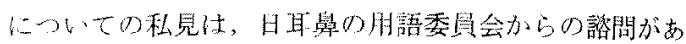
扎尤具申したい。

(B $80-1222-40545)$

\section{7、睡眠による上気道狭窄といびき発生の背景について}

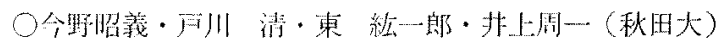

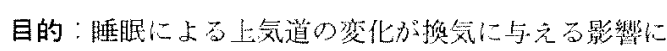

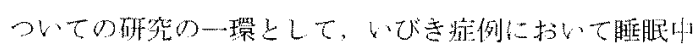

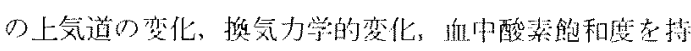

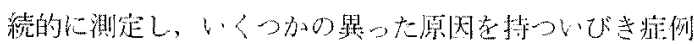

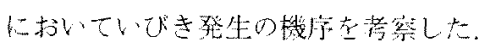

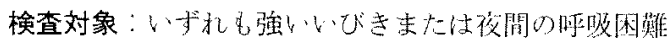

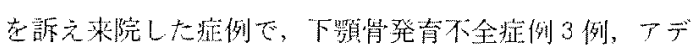

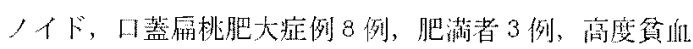

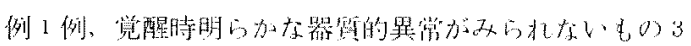
例である。

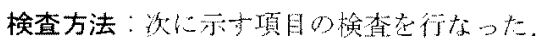

(1) Impedance pneumograph (

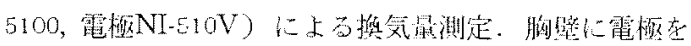

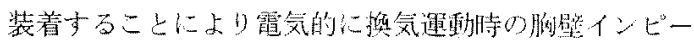

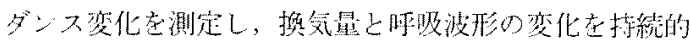

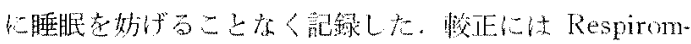
eter（シチズン河口湖精機）走用いた。

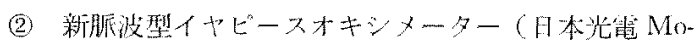

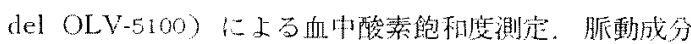
を入力とするものて耳众装着に上り和中（動㭽血）の酸

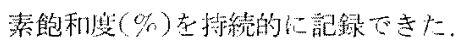

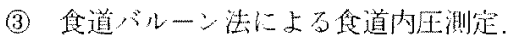

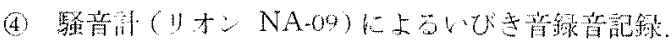

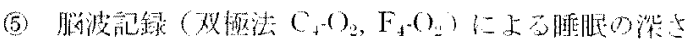

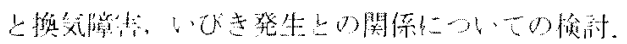

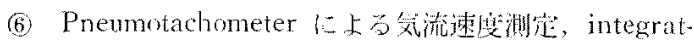

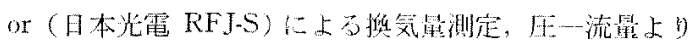
脚粘生抵满の測它。

(7) X淙透視に上万睡眠小の受道形热変化の推察.

(8) フォイドスープ (Machida RH 150TL) 亿古 気道形態の変化，振動㥞式の钼察。

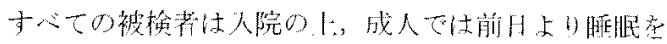

制限し，深䂭に㛟查を行なった（1)〜(4)は全例に行な い，(5〜8は一部の症例に行なった，特に(8)の梌查は卜

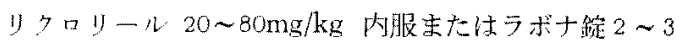
鏔（成人）服用聁の睡眠の状態を行なった。

[成續] I 陉気力学的变化

睡㛧による撸気運動の变化，六道抵抗增加の程度は症例 に上り，牛间一症何においても睡眠の深さにより大き 〈变化し，全体上して定量的に表現することは困難であ るが，才心ての腚例に拈いて睡眠により気道抵抗の增

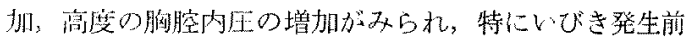

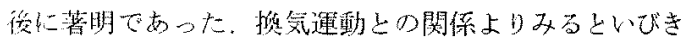
杜次の2つの型に大きく分類することができた。

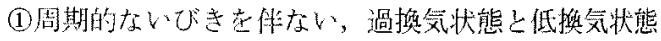

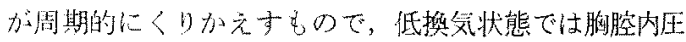
沬蓠度に增加し，竟醒時の倍以上に達することも多く，

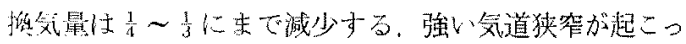
ていることを示す。このよらな状態が長期閒持続した症

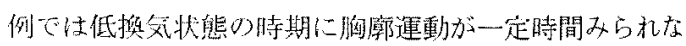

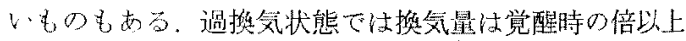
末で增加する，胸腔内压も倍にまで増加している，狭窄

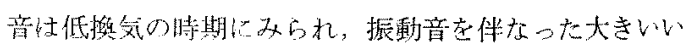
びきは逗掺気の時期に双られる，酸素飽和度の変化をみ

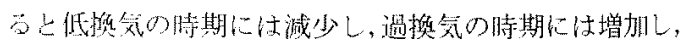

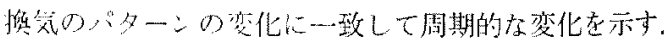

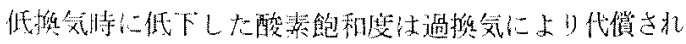

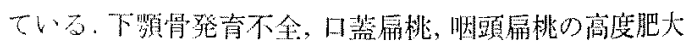

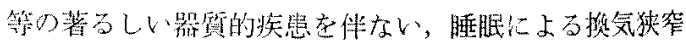

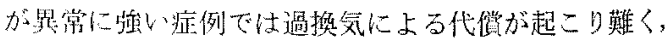
肺性心に発展するこ上が稀にある。脳波によ吕睡眠の深

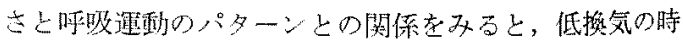

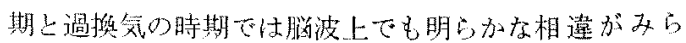

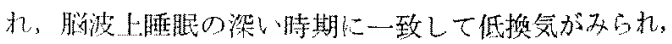

